\title{
The Role of Achievement, Gender, SES, Location, and Policy in Explaining the Indigenous Gap in High-School Completion
}

Melissa Schellekens

Australian Catholic University, Institute for Positive Psychology and Education

33 Berry Street, North Sydney, 2060

melissa.schellekens@myacu.edu.au

Anthony Dillon

Australian Catholic University, Institute for Positive Psychology and Education

33 Berry Street, North Sydney, 2060

anthony.dillon@acu.edu.au

Robert Brockman

Australian Catholic University, Institute for Positive Psychology and Education

33 Berry Street, North Sydney, 2060

robert.brockman@acu.edu.au
Joseph Ciarrochi

Australian Catholic University, Institute for Positive Psychology and Education

33 Berry Street, North Sydney, 2060

joseph.ciarrochi@acu.edu.au

Baljinder Sahdra

Australian Catholic University, Institute for Positive Psychology and Education

33 Berry Street, North Sydney, 2060

baljinder.sahdra@,acu.edu.au

Janet Mooney

Australian Catholic University, Institute for Positive Psychology and Education

33 Berry Street, North Sydney, 2060 janet.mooney@acu.edu.au

Philip Parker*

*Corresponding author

Australian Catholic University, Institute for Positive Psychology and Education

33 Berry Street, North Sydney, 2060

philip.parker@acu.edu.au

ORCID: 0000-0002-4604-8566 
The Role of Achievement, Gender, SES, Location, and Policy in Explaining the Indigenous Gap in High-School Completion

Abstract

Internationally there is a gap in high school completion rates for Indigenous and non-Indigenous students. In Australia, gap estimates are commonly based on lag indicators, precluding examination of underlying mechanisms. Using two longitudinal and representative samples of Australian youth, we explored differences in high school completion between Australian Indigenous and non-Indigenous rates and whether the gap varies for students of similar academic ability. Using an intersectional approach, we show the Indigenous gap varies by SES and location. Specifically, high SES and living in urban settings are protective factors for non-Indigenous students, but not so for Indigenous students. Results also show the Indigenous gap declined in response to government policy that increased the compulsory school leaving age.

Keywords: High school completion, Dropout, Indigenous, Socioeconomic status 
INDIGENOUS SCHOOL COMPLETION 2

\section{The Role of Achievement, Gender, SES, Location, and Policy in Explaining the Indigenous Gap in High-School Completion}

Internationally, education gaps are rampant for Indigenous youth compared to their non-Indigenous counterparts (Calver, 2015; Chain et al., 2017). In Australia, where this problem is particularly salient (Song et al., 2014), the federal government publishes yearly 'Closing the Gap' reports which set and evaluate national targets related to Indigenous health, education, and well-being (Australian Government, 2020). One of the key targets is to halve the gap for Indigenous Australians in Year 12 attainment or equivalent attainment by 2020. Closing the high school completion gap is a goal of the Australian government because of the link between high school completion and access to secure, full-time, and prestigious jobs and occupations (Australian Government, 2020; Lamb, 2011). In 2008, only 45\% of Indigenous youth graduated high school, a 40 percentage-point gap to non-Indigenous students. But the latest report has shown an improvement for Indigenous students to $66 \%$ for $2018-2019$ with the gap narrowing to 25 percentage-points (Australian Government, 2020). Importantly, this statistic is based on lag indicators (i.e., proportion of 20-24 years olds who have completed high school) not on lead indicators that could be best estimated via longitudinal data that follows students through high school. Use of longitudinal data would also allow research to examine mechanisms that may help explain this gap.

The current research aims to explore the gap in high school completion between Indigenous and non-Indigenous youth using two longitudinal samples starting in 2003 and 2009. Informed by Boudon's (1974) Primary (academic achievement influences) and Secondary (non-achievement related influences) mechanism distinction, we also consider the size of this gap for students with similar levels of academic ability. Informed by Indigenous approaches to 
intersectionality (e.g., Walter, 2015) we take a quantitative intersectional approach (Else-Quest \& Hyde, 2016a, 2016b) where intersectionality is defined as "the various ways in which multiple social categorizations interact to shape the dimensions of the experiences of individuals" (Jang, 2018, p. 1269). Accordingly, we consider whether the gap varies according to gender, socioeconomic status, and place. Finally, taking advantage of a multi-cohort representative longitudinal study we explore whether high school completion gaps were influenced by a change in government policies that lifted the compulsory school leaving age across Australia to 17 years of age; a policy intervention other countries have employed to try to increase high school completion levels (Markussen \& Sandberg, 2011) and which has been shown to have a positive influence on high school completion (Rumberger, 2011a). We provide a test of whether such a policy helps close gaps in Indigenous educational disadvantage.

\section{Indigenous Education and High School Completion: An International Concern}

Closing the education gap for Indigenous young people is increasingly an international issue. In the United States the achievement gap for Native American students has widened as academic achievement increases in the general student population. Based upon an analysis of the National Assessment for Educational Progress, a large nationally representative math and reading exam that samples $4^{\text {th }}, 8^{\text {th }}$, and $12^{\text {th }}$ grade students throughout the United States, Fischer and Stoddard (2013) report a raw achievement gap of about 60-70 percent of a standard deviation for both math and reading for Native American students, a gap that widens with age. Statistics out of Canada report a remarkably similar story. For example, Calver (2015) reports similar raw achievement gaps to the US that translate into gaps in high school completion. Canadian Aboriginal student high school completion rates are about $72 \%$ compared to 
non-Aboriginal students at $88 \%$. Calver reported that this gap also translated into lower participation rates in university education for Canadian Aboriginal students. Researchers from Australia and New Zealand studying their respective Indigenous student populations report similar results. Song, Perry, \& McConney (2014) in their analysis of the PISA results from Australia and New Zealand, found significant achievement gaps exist for their respective Indigenous students.

Consistent educational gaps for Indigenous people have been highlighted by the UN Indigenous Peoples group as a major international concern (UNDESA, 2020). Indigenous groups also share similar barriers to educational access as many ethnic minorities-particularly in multi-nation states - in many countries across the world (Kymlicka, 2009). For this reason, research on Indigenous disadvantage is an international concern. Thus, while we focus on Australia, we expect many of the findings to be relevant to issues of Indigenous educational inequality, and indeed ethnic minority inequality, internationally.

\section{High School Completion}

Failure to complete high school can have dire consequences. In this article, when discussing Indigenous Australians, we are mostly concerned with non-completion of high school (i.e., graduation from high-school). However, we do make reference to dropout, which is a slightly different, yet closely related phenomena. While successful completion of high school opens pathways to work, further education, and social mobility, dropping out has significant negative personal and social consequences (Lamb \& Huo, 2017; Lamb \& Markussen, 2011). Not completing high school is likely to negatively influence young people's future educational attainment and career prospects (Rumberger, 2011b). Indeed, failure to complete high school, 
and increasingly failure to complete college, have attainment disadvantages that have grown over time (Bowen et al., 2009). Compared to high school graduates, dropouts have higher unemployment and reduced earnings (Rumberger, 2011b). With greater social service dependency and lower tax contributions (Lansford et al., 2016; Waldfogel et al., 2005) than their graduated peers, the financial cost to society of those who drop out is enormous. For example, for the almost 38,000 young Australians who dropped out in 2014 and will never finish high school, the financial cost to taxpayers is estimated at over $\$ 315$ million per year (Lamb \& Huo, 2017). For Indigenous Australians specifically, the potential gains from reducing the disadvantage associated with reduced employment and education opportunities are substantial. Addressing Indigenous disadvantage will benefit government budgets in the form of higher revenues and lower expenditure (Deloitte Access Economics, 2014). Specifically, if the circumstances of Indigenous Australians improve to match those of the Australian average, then by 2031, governments across Australia would experience a net gain of $\$ 11.9$ billion.

A strong association between dropout and negative health outcomes exists (Muennig, 2007), with early leavers exhibiting higher rates of depression (Rumberger, 2011b), illicit substance use (Lansford et al., 2016), and ultimately earlier mortality (Molla et al., 2004) than their graduating peers. In addition, early leavers exhibit more criminal behaviour and spend more time incarcerated (Lansford et al., 2016; Rumberger, 2011b).

High school graduation is increasingly seen as the minimum educational attainment needed for the successful participation of young people in work and further study (Lamb \& Markussen, 2011). Consequently, young people are increasingly graduating from high school and staying in education longer to secure employment (Piketty, 2014). Because more young 
people are graduating than ever before, those without a secondary education are being left further behind (Goldin, 2018). Across Organization for Economic Cooperation and Development (OECD) member countries, high school graduation increased by 6 percentage points on average from 2005 to 2017 . While this is encouraging, $15 \%$ of 25 to 35 year-olds had not successfully completed upper secondary education in 2018 (OECD, 2019). The negative consequences of dropping out appear to be worsening as greater demands are made by employers for a more educated workforce (Lamb et al., 2015; Rumberger, 2011b).

The rich, profound, and long-lasting culture and traditions of Australian Indigenous people have great strengths, yet in what manner has Australia's education system not worked with Indigenous Australian's to capitalise on their strengths and talents to promote better school participation? Internationally, Indigenous adolescents have higher rates of dropout than non-Indigenous adolescents (Adelman et al., 2018; Garrett et al., 2014; Johnston-Goodstar \& VeLure Roholt, 2017; Lees, 2016; Manojan, 2018; Singar \& Zainuddin, 2017; UNDESA, 2020). A "significant and sizable Indigenous effect" has been demonstrated by Author (2015) in predicting adolescent university entry, to be attributable to non-academic achievement related mechanisms like distinct patterns of Indigenous social capital, lower racial capital (see below), relative risk aversion, and structural barriers including Bourdieu's concept of symbolic violence, and racism and prejudice (Author, 2020; Bodkin-Andrews et al., 2010; Sikora \& Biddle, 2015; Walter, 2015). In part, this is due to the family, school, and community environments of Indigenous young people varying in unique ways from that of the majority adolescent populations (Guenther \& Osborne, 2018). 
INDIGENOUS SCHOOL COMPLETION 7

\section{Primary and Secondary Effects Model and an Indigenous Intersectionality}

Boudon (1974) noted the critical importance in educational inequality of distinguishing between primary (achievement related) and secondary (non-achievement related) pathways. Primary pathways acknowledge the now persistent findings that disadvantaged groups have lower academic achievement levels than their more advantaged peers. For example, Indigenous youth have scored lower in academic achievement at every PISA cycle (De Bortoli \& Thomson, 2010; Song et al., 2014; Thomson et al., 2013). Secondary pathways consider the counterfactual condition of the gap in educational outcomes between advantaged and disadvantaged peers who have the same level of academic achievement. Author (2015) found that approximately half of the Indigenous disadvantage in university entry was due to these secondary effects (including the mechanisms outlined in the previous section). As secondary effects reflect the residual disadvantage in education outcomes, they capture a large range of "non-meritocratic" mechanisms of inequality. We note that the concept of meritocracy in education is deeply problematic (see Brown, 2010). But equally, disadvantages in educational outcomes that are present even after controlling for achievement are uniquely concerning. It is for this reason we place considerable emphasis on knowing: a) whether gaps exist between Indigenous and non-Indigenous youth in high school completion; and b) whether these gaps persist when controlling for academic achievement - that is when comparing equally achieving Indigenous and non-Indigenous youth.

While primary and secondary effects provide a useful framework, the theory is limited by an underlying assumption of relative homogeneity within groups. Social scientists have long 
been obsessed with average causal effects ${ }^{1}$ (Morgan \& Winship, 2015). Indigenous research has itself been dominated by well-meaning research that treats Indigenous peoples as homogenous, potentially exacerbating internal conflicts and inequalities (Osborne et al., 2019). As Walter (2015) notes, intersectional perspectives for Indigenous issues, particularly in relation to social class, gender, and geography, are critical. Returning to the concept of capital provides an Indigenous intersectional hypothesis that socioeconomic status will be less beneficial for Indigenous peoples' educational outcomes than for non-Indigenous youth. Walter (2015) argues that Indigenous youth lack the racial capital that is critical to educational success. Racial (or ethnic) capital reflects a person's access to opportunities, resources, and other forms of capital due to their race or ethnicity (Kim, 2019; Waring, 2017). Author (2020) argues that a lack of racial capital restricts Indigenous youths' ability to access and deploy other forms of capital commonly associated with advantaged socioeconomic position. Consistent with this argument, they show that socioeconomic status has a weaker relationship with university entry for Indigenous youth than for non-Indigenous youth. The lack of effect of socioeconomic status on educational attainment for Indigenous youth is striking given the strong relationship observed in general population samples (Dalton et al., 2009; Devenish et al., 2017; Kim et al., 2019; Lamb \& Huo, 2017; Polidano et al., 2013; Sznitman et al., 2017).

Again showing the importance of taking an intersectional perspective, Sikora and Biddle (2015) found that the gender gap in educational and occupational expectations was generally

\footnotetext{
${ }^{1}$ It is important to note that one aspect of heterogeneity we could not explore was that within the category of Indigenous Australian's itself. We stress that readers should recognize that the label Indigenous Australian obscures the distinctiveness between not only Aboriginal and Torres Strait Islander peoples, but also the immense diversity of language groups and cultural values across Aboriginal and Torres Strait Islander peoples (Purdie et al., 2010). We simply retain the label of Indigenous Australian to in recognition that this is a social category that directly shapes the lives of many Australian people.
} 
larger-favoring females — among Indigenous youth than non-Indigenous youth. It is also likely that the influence of Indigenous status on school completion is dependent on place. Place for Indigenous youth is often associated not just with physical distance between urban and rural but with cultural distance with rural and remote Indigenous youth often having different ontological, cosmological, epistemological, and axiological orientations than their urban Indigenous peers (Guenther \& Osborne, 2018; McRae-Williams, 2014). This may influence the approach and value rural and remote Indigenous students have to education and may be one of the reasons that educational attainment tends to be lower in rural and remote locations (Gray et al., 2000). Though it should be stated that macro-structural issues also place a large role in the rural/urban divide with declining economic fortunes in rural locations likely hitting Indigenous people harder than their rural non-Indigenous peers (Gray et al., 2000). The issue of declining rural fortunes and how they affect already vulnerable groups is an issue shared by other Anglophone countries (Carr \& Kefalas, 2010; Tieken, 2014).

Thus, with respect to the aims of this paper, we not only consider whether there is an Indigenous disadvantage in high school completion and whether this gap persists for equally able children but also whether this gap varies as a function of socioeconomic status, gender, and geography. We do this via a quantitative approach to intersectionality proposed by Else-Quest and Hyde (2016a, 2016b) in which the interaction between multiple forms of marginalized or minority status are considered.

\section{Policy Effects}

Research indicates that system-level educational policies can increase school completion (Markussen \& Sandberg, 2011). Numerous Anglophone countries have increased compulsory 
school-leaving age in the belief that numbers of students obtaining upper secondary qualifications will increase (Markussen \& Sandberg, 2011). In Australia, compulsory school-leaving age was increased from 15 to 17 years from 2006 to 2010 , leading to an increase in retention rates from secondary school to senior high school (Author et al., 2019). Increasing the compulsory school-leaving age of students has been implemented with the belief that adolescents who stay in school longer are more likely to complete high school. This lifting of the age that one is legally able to leave formal schooling has been associated with increased retention in subsequent non-compulsory years, and with lower dropout rates and higher graduation rates in various states of the United States (Rumberger, 2011a). It is therefore expected that increasing compulsory school-leaving age that occured in Australia between 2006 and 2010 is associated with higher rates of school completion. But did it help close the Indigenous gap in school completion?

As we outlined above, closing the year 12 completion rate gap between Indigenous and non-Indigenous is one of the Australia Government's priorities. Thus, it is crucial to evaluate whether this policy, directly aimed at increasing completion rates, has helped the government meet its Closing The Gap obligations. As noted above, many countries have implemented policies that raise the compulsory school leaving age. Yet there is relatively little research that has assessed the success of these policies in terms of increasing equity in school completion. Such policies may lift school completion systematically - that is equally for both vulnerable and advantaged populations - and thus not decrease existing relative inequalities. Thus, the current research has important implications beyond Australia. 
INDIGENOUS SCHOOL COMPLETION 11

\section{Hypotheses and Research Questions}

Hypothesis 1a. There is a gap between Indigenous and non-Indigenous students in high school completion rates.

Hypothesis $1 \mathrm{~b}$. This gap varies as a function of socioeconomic status, gender, and place (urban or rural).

Hypothesis 1c. This gap narrowed as a function of a change in legislation that increased the compulsory school leaving age to 17 between 2008 and 2010.

Hypothesis 2a. There is a gap between Indigenous and similar achieving non-Indigenous students in high school completion rates.

Hypothesis $2 \mathrm{~b}$. This gap varies as a function of socioeconomic status, gender, and place (urban or rural).

Hypothesis 2c. This gap narrowed as a function of a change in legislation that increased the effective age of first selection to 17 between 2008 and 2010.

Hypothesis $2 \mathrm{~d}$ (Research question). Does this gap vary as a function of academic achievement? That is, is the gap between similarly low achieving Indigenous and non-Indigenous children the same as the gap between similarly high achieving Indigenous and non-Indigenous children?

\section{Methods}

\section{Participants}

This study is based on publicly available data from two cohorts of a nationally representative and large-scale longitudinal Australian database, the Longitudinal Surveys of Australian Youth (LSAY). LSAY follows cohorts of young people from the age of 15 enrolled at school, contacting them once a year for ten years until age 25. The samples used in this study 
come from the LSAY 2003 cohort (Y03) $(N=12,551 ; 50.82 \%$ male) and from the LSAY 2009 cohort (Y09) $(N=14,251 ; 48.90 \%$ male). Sampling involved the initial data collection of the Programme for International Student Assessment (PISA) in the first year and follow-up telephone interviews of the LSAY questionnaire conducted annually (NCVER, 2014; NCVER, 2018). PISA sampling, conducted by the OECD, involved a complex two-stage clustered sampling design. In the first stage, school selection was based on probability proportional to school size, where larger schools were more likely to be chosen. A total of 355 schools in 2003, and 353 schools in 2009, were selected. The sample was designed to be representative of students across Australia in terms of state/territory, school sector and metropolitan/regional areas. The second stage of PISA sampling involved random selection of a set number of non-Indigenous students (50 in Y2003 and 48 in Y2009), and all Indigenous 15 year-old adolescents, at each sampled school. At schools with fewer than the set number of students, all 15 year-olds were selected. Indigenous students and areas with less participants were over-sampled to allow representative results to be produced by Indigenous status and state (NCVER, 2018).

\section{Variables}

Non-completion of high school, the dependent variable, was based on the derived variables that measure whether the adolescent had left school before completing year 12, had completed year 12 or was still at school. Adolescent Indigenous status was determined by asking “are you of Aboriginal or Torres Strait Islander heritage?” (1 = identifies as being of Indigenous Australian or Torres Strait Islander heritage, $0=$ identifies as being of neither heritage). Adolescent socioeconomic background was obtained using an index of economic, social, and 
cultural status - the PISA ESCS index-based on adolescent self-report of highest level of parental education, highest status parental occupation, and home possessions including wealth, cultural possessions and home education resources. An academic achievement index was derived using a principal component of the PISA math, reading, and science scores. Place was measured on the basis of whether the student was located in an urban or rural location based on Australian Bureau of Statistics postcode assignments. Gender was self-reported as male or female. And cohort was assigned as a 0 if the participant was in the 2003 cohort or 1 if the participant was in the 2009 cohort. We also controlled for Year in school (hereafter Grade) for the first time wave. State of residence was also controlled for. However, when including state there were some empty cells in the more complex models. As such we choose to report models without state. The results were almost identical in both cases.

\section{Analysis}

All models were estimated using logistic regression with a binomial link function. These models were estimated with the combined attrition weights and sample weights, and Fay replication weights (rho $=.5$ ) to account for clustering within schools using the survey package in R (Lumley, 2011). Results are presented in log odds with marginal effects for predicted probabilities of not completing high school plotted for focal comparisons. Marginal effects are evaluated at the simple average for all other variables.

\section{Missing Data}

To account for attrition in our sample from the first LSAY wave to the second we used the attrition weights provided by the survey organisers. Once attrition was accounted for there was very little missing data $(<0.6 \%)$. Our rationale for focusing on high school continuance and 
completion rates from wave 2 in LSAY is due to the fairly steep attrition in subsequent waves that is of particular concern here given the relatively modest sample of Indigenous students in the initial sample. This would have resulted in underpowered tests of our hypotheses. In addition, the vast majority of the sample was in Grade 10 at the first wave with non-completion from Grade 10 to 11 being a particularly crucial transition (see ABS report 4221.0). Thus, focusing on waves 1 to 2 provided a pragmatic approach to the data. Noting that students may remain in school at wave 2 but dropout in subsequent waves, we used information on high school continuance and completion information in LSAY waves 3 to 5 to update our primary outcome variable (last observation carried backward). Much on the sample was missing due to attrition in these later waves. To account for this we include a missing by attrition flag ( 1 for missing at wave 5 and 0 otherwise) to all models.

\section{Results}

Descriptive statistics are presented in Table 1. Indigenous students have much higher non-completion rates than their non-Indigenous counterparts, as well as lower achievement and SES. The gender and Urban/non-Urban balance was close to $50 \%$.

\section{Hypothesis 1a. There is a Gap Between Indigenous and non-Indigenous Youth in the Probability of Failing to Complete High School}

We next examined the main effects of Indigenous status and our key covariates on non-completion. As expected, there was a significant main effect of Indigenous status on non-completion $(\log$-odds $=0.365,95 \%$ CI $[0.133,0.596])$. The average marginal effects suggest a $.12[.11, .13]$ probability of not completing high school for non-Indigenous youth compared to $.16[.13, .19]$ for Indigenous youth. 

High school Completion.

We next examined whether socioeconomic status, gender, place, or cohort (before or after change in compulsory school leaving age), impacts the rate of high school completion. These hypotheses were examined with moderators tested one at a time (single-interaction) or simultaneously (multiple-interaction); main effects for all covariates were included in each model and full results can be found in supplementary materials (S1 to S4). As shown in Table 2, SES moderated the link between Indigenous status and non-completion. There was also evidence of location moderation effects in the single-interaction but not in the multiple-interaction model. Cohort also had a significant moderation effect in the multiple-interaction model but not the single-interaction model. Figure 1 provides an illustration of these effects.

Higher SES conveyed little advantage amongst Indigenous youth, but a substantial benefit amongst non-Indigenous youth, in terms of high school completion. Surprisingly, there was a bigger gap between rural and urban children who were non-Indigenous than Indigenous. The policy change of increasing the compulsory school leaving age appeared to be successful in closing the gap, with Indigenous children experiencing a greater decline in the probability of not completing high school than did non-Indigenous children.

Hypothesis 2a: Indigenous and non-Indigenous Children with the Same Level of Achievement do not Differ in Probability of not Completing High school

Consistent with Boudon's Primary and Secondary Effects model we next considered whether there was a gap in probability of not completing high school for equally able Indigenous and non-Indigenous children. Controlling for achievement in the model used to test Hypothesis 1a reduced the effect of Indigenous status on high school non-completion substantially (Log Odds $=.136,95 \%$ CI [-.094, 
.365]; See S5 for full results). Marginal probabilities indicated both Indigenous and non-Indigenous children had a probability of not completing high school of $\sim .10$. Figure 2 illustrates both the achievement distribution and high school non-completion for Indigenous and non-Indigenous children.

\section{Hypothesis 2b-d: Achievement, SES, and Place Moderate the Probability of not}

\section{Completing High School for Equally Achieving Indigenous and non-Indigenous Children.}

Table 3 presents a summary of the key moderation effects (please see S6 to S11 for full results) for Indigenous and non-Indigenous children on the probability of not completing high school. Figure 3 illustrates these effects. The differential influence of socioeconomic status between Indigenous and non-Indigenous children was consistent with the findings for Hypothesis 1b. For non-Indigenous children of equal achievement, there was a clear socioeconomic status gradient to the probability of not completing high school. For equally achieving Indigenous children, socioeconomic status had little influence on not completing high school. The surprising finding from Hypothesis 1b, that place had a greater influence on non-Indigenous children than Indigenous children, was replicated here after controlling for achievement. There was no significant moderation by cohort, indicating that increasing the compulsory school leaving age did not close the gap when comparing equally achieving Indigenous and non-Indigenous youth.

Finally, achievement also moderated the effect of Indigenous status on school completion

for equally achieving Indigneous and non-Indigenous peers. As Figure 3 shows, significant secondary effects (gaps in the probability of not completing high school between equally achieving Indigenous and non-Indigenous children) only appeared in the bottom end of the achievement distribution. 
INDIGENOUS SCHOOL COMPLETION 17

\section{Discussion}

Educational disadvantage in Indigenous populations is an international concern. In particular, closing the gap in Indigenous high school completion is a major goal of governments, Quangos, and Not-for-profits. To achieve this aim we need more than descriptive research. We also need to narrow down what mechanisms are involved. In addition, for policy to be effective, it cannot treat Indigenous children as a single homogeneous group. Failure to recognize their diversity will compromise the school experience of Indigenous students.

The purpose of this paper was to explore disparities in high school completion between Indigenous and non-Indigenous Australian youth. Using Boudon's (1974) primary and secondary effects theory, we explored gaps in high school non-completion both in total and for equally achieving Indigenous and non-Indigenous students. Using a qualitative intersectional perspective (Else-Quest \& Hyde, 2016a, 2016b) we also considered if the Indigenous gap in high school non-completion varied as a function of SES, gender, and place. Such an approach provides more useful information for policy and intervention, going beyond a mere reporting of gaps that can contribute to a deficit view of Indigenous Australians (Fogarty et al., 2017). Finally, by exploring a policy response that many countries have used to try to increase high school completion, we tested whether the Indigenous gap in high school non-completion narrowed from 2004 to 2010 after Australia increased the compulsory school leaving age. We found: a) that there was a notable gap in Indigenous and non-Indigenous high school non-completion; b) this gap disappeared almost completely when comparing equally achieving Indigenous and non-Indigenous youth; c) that the gap narrowed after Australia raised the compulsory school leaving age; and d) that Indigenous children from all different social backgrounds had 
surprisingly similar levels of high school non-completion, while non-Indigenous children's rates of high school non-completion varied as a function of SES background in particular, but also place.

\section{Comparing Equal Achieving Indigenous and non-Indigenous Youth}

We found that Indigenous students were less likely to complete high school than non-Indigenous students (marginal probabilities of .12 and .16 respectively). An obvious driver of high school completion is academic achievement (primary effect). Indeed, when controlling for achievement, we found no difference in high school non-completion (see Figure 2). Academic achievement is known to be lower for Indigenous students (Author et al., 2020) and clearly impacts on school completion, and hence, post school options (e.g., university participation). Data from national benchmarking in Australia (NAPLAN) held by ACARA (https://www.acara.edu.au) shows the proportion of Indigenous students meeting national standards in numeracy to be approximately 10 percentage points less than that for non-Indigenous students in 2018. Further, for reading, the gap is approximately 20 percentage points. This is a concern as achievement gaps have been shown to be relatively resilient to change in high school (Heckman, 2006). The finding that the gap in high school completion is eliminated when achievement is controlled for, suggests that interventions most likely to close the high school non-completion gap may be preschool interventions like the Perry preschool program and Head Start (Heckman, 2017). Recent research suggests that these early education programs benefit from, and magnify the benefit of, access to high-quality schooling (Johnson \& Jackson, 2019). Reaffirming the value of early intervention, in research looking at children in Australia's Northern Territory, Silburn et al. (2018) demonstrated a positive association between 
preschool attendance and attendance in the early years of primary school, which has a positive influence on NAPLAN outcomes. They found that children who had attended preschool, then attended up to between 11 and 22 more school days per year depending on the type of preschool attended (i.e., general preschool, early years class, mobile preschool). The association between preschool attendance and early primary school attendance was statistically significant for both Indigenous and non-Indigenous students across all remoteness strata, but was stronger for Indigenous students.

An intervention that may be successful in improving high school completion rates for Indigenous students, based on our results, is the increase of compulsory school leaving age. Previous research has shown that such a policy intervention is effective in improving a country's high school completion rates (Rumberger, 2011a). Our research suggests this policy change was particularly advantageous for Indigenous students, whose non-completion rates dropped to a greater degree than non-Indigenous students from 2004-2010. The signal in our data about the effectiveness of raising compulsory school leaving ages and the likely importance of pre-school interventions emphasises the need for a whole of education approach to reducing the gap in Indigenous education.

\section{Intersectionality}

We also focused on how the school completion gap between Indgenous and non-Indigenous youth varied according to SES, place (i.e., urban, provincial), and gender. Our findings show that although there was no variation for gender, both SES and location moderated the link between Indigenous status and non-completion, with the moderation association also present after controlling for achievement. Perhaps surprisingly, the overall finding from these 
analyses was that Indigenous youth's risk of non-completion was relatively stable across the SES gradient and approximately equal in both urban and rural settings. In contrast, high school non-completion was quite responsive to SES and place for non-Indigenous youth. While the literature has consistently shown a clear SES divide on many educational outcomes (e.g., Reardon, 2011), the current study shows this appears to not be the case for Indigenous students. But why might socioeconomic status be less protective for Indigenous adolescents in preventing non-completion than for non-Indigenous students? One explanation is accounted for by the Sen-Bourdieu framework (Pham, 2019). Under this framework, a student's stock of capital (cultural and social) represents the habitus, that is, the norms, skills and dispositions, of their past experience and family background (Bourdieu, 2006), which shapes their school attitudes, participation, and behaviour. Under this framework, Indigenous and non-Indigenous students possess different social capital (Author, 2020) and differing interplays between forms of capital. The different forms of capital and their interaction influences how easily social and cultural capital can be transformed to economic capital, and, in turn, into educational capability and the opportunities students' perceive as available. A school's policies and practices determine the extent that a student's forms of capital assist or limit their capacity to transfer resources to educational capability (Pham, 2019).

The particular form of capital that is relevant here is racial capital. Previous research that has shown a lack of SES gradient in educational outcomes among Indigenous people has argued this may be due to Indigenous people's poorer access to racial capital (Author, 2020; Walter, 2015). Other possibilities are that forms of social and cultural capital available to high SES non-Indigenous youth are not readily available to Indigenous youth or that Indigenous specific 
forms of capital are poorly valued by Western society essentially flattening the SES gradient in relation to educational outcomes. Where Indigenous cultural capital is valued, for example in culture-based education in Hawaii, culture may be advantageous to positively influencing the educational outcomes of Indigenous students (Kana'iaupuni et al., 2017; Lees, 2016). In addition, full service community schools have shown potential in building social capital to improve educational outcomes and reduce educational inequality in low-income communities (Galindo et al., 2017).

Table 3 indicates that for equally achieving Indigenous and non-Indigenous children, school completion is moderated by achievement level. From Figure 3 it would appear that a moderating effect occurs for students of low academic ability. Specifically, for Indigenous and non-Indigenous children of equal low ability, Indigenous students were more likely to complete high school. This finding may be due to non-Indigenous students and their families having a social capital that can afford them opportunities external to formal schooling (vocational education, jobs, or apprenticeships) that do not require Year 12 completion. Further, the finding that low achieving Indigenous students were slightly more likely to complete high school (compared to equally achieving non-Indigenous students), as depicted in Figure 3, may reflect the success of targeted programs (e.g., Clontarf Foundation; Oliver \& Exell, 2019) and government policies that aim to inform Indigenous students and their families about the importance of high school completion, and support them through to completion.

At the other end of the achievement distribution, high-achieving Indigenous youth appeared to have higher rates of high school non-completion than comparably achieving non-Indigenous youth. This may suggest that it is important to have specific programs for 
academically gifted Indigenous students that engage such promising youth to remain in school. High-achieving Indigenous youth not completing high school represents a significant waste of talent.

\section{International Indigenous Populations}

Indigenous Australians with their history of colonisation, dispossession, and marginalisation, share many experiences with other Indigenous people around the world (Prout \& Hill, 2012). Indigenous Australian's educational disadvantage is mirrored internationally (UNDESA, 2020). Table 4 summarises the UNDESA concerns about Indigenous education globally and thus what likely educational interventions may need to target. The available literature and findings of this research highlight these outcomes (i.e., poor attendance, lower academic achievement, reduced completion rates) as well as ways forward (e.g., increased compulsory school-leaving age). Given the similar histories, minority group status, and marginalisation, to Australian Indigenous people, these findings have relevance for other Indigenous populations around the world.

\section{Limitations and Further Directions}

The current study contains a limitation common to all PISA studies; including longitudinal studies like the present that use a PISA sample as their base. PISA is a study that is representative of the in-school population of 15 -year-olds. This means that there is a hidden selection variable that excludes from consideration the population of 15 -year-olds who have dropped-out of school before the age of 15 . This tends to be a larger concern for low and middle income countries compared to countries like Australia (Wils, Sheehan, \& Shi, 2019). However, Australian Indigenous students are more likely to drop-out of school early. Irregular school 
attendance can also be a reason for exclusion from PISA. For example, in some rural and remote communities, students could have very irregular attendance due to family mobility and are therefore unlikely to be considered for inclusion in PISA (Prout \& Hill, 2012; Sarra, 2014). This likely means that the estimation of school non-completion for Indigenous students is lower than the likely true rate in the population.

Another limitation is the attrition rate in LSAY, which leads us to focus most strongly on the pathway of students through school at traditional age-graded rates. However, Indigenous students may take non-traditional pathways through school that mean they graduate later or through alternative channels (Biddle et al., 2014; Jorgensen, 2020). It is worth noting, however, that life-time attainment rates tend to be best for people who take traditional developmental pathways consistent with socially age-graded transitions. Indeed, it is now well established that students in the US who take traditional pathways at typical ages tend to fare better than those that take alternative pathways like the General Education Development test (Rumberger, 2011a).

Finally, given the far-reaching impact of non-completion of high school, more research is needed. Future research needs to stretch further into the post-schooling years to explore the long-term attainment outcomes of Indigenous and non-Indigenous students (from different social identity groups) who fail to complete high school. Future research should also focus on developing a model of non-completion for Australian Indigenous students. Rumberger (2011a) summarises several models that provide a useful means to understanding why students drop out of high school. While each of these models has some relevance to Indigenous students, there is much to gain from developing a model that incorporates intersectionality and takes into account the special characteristics of Indigeous students. 
INDIGENOUS SCHOOL COMPLETION 24

\section{Conclusion}

Indigenous children in Australia are less likely to complete high school than non-Indigenous children. This is similarly true for Indigenous children of other countries around the world. This longitudinal study of Australian Indigenous and non-Indigenous students indicates that a significant contributor to the lower school completion rates for Indigenous students is the primary effect of lower academic achievement rates. Encouragingly, our analysis of potential secondary effects found that Indigenous students' probability of dropping out of high school were very similar to non-Indigenous students of similar academic ability. Further, the probability of high school completion for non-Indigenous students was impacted by both location and SES, but not so for Indigenous students. High SES and living in urban settings were identified as protective factors for non-Indigenous students in terms of high school completion. For Indigenous students, no such protection benefits were evident. The current results suggest that raising compulsory school leaving ages and investing in pre-school interventions are likely to improve educational outcomes for Indigenous children and reduce the gap in high school completion.

\section{References}

Author (2020)

Author (2015)

Author (2019)

Author (2020)

Adelman, M., Haimovich, F., Ham, A., \& Vazquez, E. (2018). Predicting school dropout with administrative data: new evidence from Guatemala and Honduras. Education Economics, 
INDIGENOUS SCHOOL COMPLETION 25

26, 356-372. https://doi.org/10.1080/09645292.2018.1433127

Australian Government. (2020). Closing the gap (Report 2020). Australian Government. https:/ctgreport.niaa.gov.au/sites/default/files/pdf/closing-the-gap-report-2020.pdf

Biddle, N., Brennan, C., \& Yap, M. (2014). Effectiveness of traineeships and apprenticeships for the Aboriginal and Torres Strait Islander population (No. 31). Closing the Gap Clearinghouse. https://openresearch-repository.anu.edu.au/handle/1885/164297

Bodkin-Andrews, G., O’Rourke, V., Grant, R., Denson, N., \& Craven, R. G. (2010). Validating racism and cultural respect: testing the psychometric properties and educational impact of perceived discrimination and multiculturation for Indigenous and non-Indigenous students. Educational Research and Evaluation, 16, 471-493. https://doi.org/10.1080/13803611.2010.550497

Boudon, R. (1974). Education, Opportunity and Social Inequality: Changing Prospects in Western Society (1st ed.). Wiley.

Bourdieu, p. (2006). The forms of capital. In H. Lauder, P. Brown, J. Dillabough, \& H. Halsey (Eds.), Education, Globalisation and Social Change (pp. 105-118). Oxford University Press.

Bowen, W., McPherson, M., \& Chingos, M. M. (2009). Crossing The Finish Line. Princeton University Press.

Brown, P. (2010). The global auction: the broken promises of education, jobs and incomes (1st ed.). Oxford University Press.

Calver, M. (2015). Calver, M. (2015). Closing the Aboriginal education gap in Canada: Assessing progress and estimating the economic benefits (No. 2015-03). Centre for the 
INDIGENOUS SCHOOL COMPLETION 26

Study of Living Standards. http://www.csls.ca/reports/csls2015-03.pdf

Carr, P. J., \& Kefalas, M. J. (2010). Hollowing out the middle: The rural brain drain and what it means for America. Beacon Press.

Chain, J., Shapiro, V. B., LeBuffe, P. A., Bryson, A. M., \& American Indian and Alaska Native Advisory Committee. (2017). Academic achievement of american indian and alaska native students: does social emotional competence reduce the impact of poverty. American Indian and Alaska Native Mental Health Research, 24, 1-29.

https://doi.org/10.5820/aian.2401.2017.1

Dalton, B., Glennie, E., \& Ingels, S. J. (2009). Late high school Dropouts: Characteristics, experiences, and changes across cohorts. Descriptive analysis report. NCES 2009-307. National Center for Education Statistics. Available from:

http://nces.ed.gov/help/orderinfo.asp. https://eric.ed.gov/?id=ED505580

Deloitte Access Economics. (2014). Economic benefits of closing the gap in Indigenous employment outcomes. Deloitte Access Economics. https://www2.deloitte.com/content/dam/Deloitte/au/Documents/finance/deloitte-au-fas-econ omic-benefits-closing-gap-10-feb-2014-240914.pdf

Devenish, B., Hooley, M., \& Mellor, D. (2017). The pathways between socioeconomic status and adolescent outcomes: A systematic review. American Journal of Community Psychology, 59, 219-238. https://doi.org/10.1002/ajcp.12115

De Bortoli, L., \& Thomson, S. (2010). Contextual factors that influence the achievement ofAustralia's Indigenousstudents: Results fromPISA 2000 - 2006. ACER. https://research.acer.edu.au/cgi/viewcontent.cgi?article=1006\&context=ozpisa 
Else-Quest, N. M., \& Hyde, J. S. (2016a). Intersectionality in quantitative psychological research. Psychology of Women Quarterly, 40, 155-170.

https://doi.org/10.1177/0361684316629797

Else-Quest, N. M., \& Hyde, J. S. (2016b). Intersectionality in quantitative psychological research. Psychology of Women Quarterly, 40, 319-336.

https://doi.org/10.1177/0361684316647953

Fischer, S., \& Stoddard, C. (2013). The academic achievement of American Indians. Economics of Education Review, 36, 135-152. https://doi.org/10.1016/j.econedurev.2013.05.005

Fogarty, W., Riddle, S., Lovell, M., \& Wilson, B. (2017). Indigenous education and literacy policy in australia: bringing learning back to the debate. The Australian Journal of Indigenous Education, 47(2), 1-13. https://doi.org/10.1017/jie.2017.18

Galindo, C., Sanders, M., \& Abel, Y. (2017). Transforming educational experiences in low-income communities. American Educational Research Journal, 54, 140S-163S. https://doi.org/10.3102/0002831216676571

Garrett, M. T., Parrish, M., Williams, C., Grayshield, L., Portman, T. A. A., Rivera, E. T., \& Maynard, E. (2014). Invited commentary: Fostering resilience among Native American youth through therapeutic intervention. Journal of Youth and Adolescence, 43(3), 470-490. https://doi.org/10.1007/s10964-013-0020-8

Goldin, C. (2018). The race between education and technology. In Inequality in the 21st century: A reader (pp. 49-54). Routledge. https://doi.org/10.4324/9780429499821-10

Gray, M. C., Hunter, B., \& Schwab, R. G. (2000). Trends in Indigenous educational participation and attainment, 1986-96. Australian Journal of Education, 44, 101-117. 
INDIGENOUS SCHOOL COMPLETION 28

https://doi.org/10.1177/000494410004400202

Guenther, J., \& Osborne, S. (2018). Red dirt education leaders 'caught in the middle': priorities for local and nonlocal leaders in remote schools. The Australian Journal of Indigenous Education, 1-13. https://doi.org/10.1017/jie.2018.17

Heckman, J. J. (2006). Skill formation and the economics of investing in disadvantaged children. Science, 312(5782), 1900-1902. https://doi.org/10.1126/science.1128898

Heckman, J. J. (2017). Giving Kids a Fair Chance (Boston Review Books) (Reprint). The MIT Press.

Jang, S. T. (2018). The implications of intersectionality on southeast asian female students' educational outcomes in the united states: A critical quantitative intersectionality analysis. American Educational Research Journal, 55, 1268-1306.

https://doi.org/10.3102/0002831218777225

Johnson, R. C., \& Jackson, C. K. (2019). Reducing Inequality through Dynamic Complementarity: Evidence from Head Start and Public School Spending. American Economic Journal: Economic Policy, 11, 310-349. https://doi.org/10.1257/pol.20180510 Johnston-Goodstar, K., \& VeLure Roholt, R. (2017). “Our kids aren’t dropping out; they’re being pushed out": Native american students and racial microaggressions in schools. Journal of Ethnic \& Cultural Diversity in Social Work, 26, 30-47. https://doi.org/10.1080/15313204.2016.1263818

Jorgensen, R. (2020). Creating opportunities for vulnerable indigenous learners to succeed in vocational education. $Z D M, 52,571-580$. https://doi.org/10.1007/s11858-019-01117-w Kana'iaupuni, S. M., Ledward, B., \& Malone, N. (2017). Mohala i ka wai. American 
Educational Research Journal, 54, 311S-339S. https://doi.org/10.3102/0002831216664779

Kim, J. (2019). Ethnic capital, migration, and citizenship: a Bourdieusian perspective. Ethnic and Racial Studies, 42, 357-385. https://doi.org/10.1080/01419870.2019.1535131

Kim, S. W., Cho, H., \& Kim, L. Y. (2019). Socioeconomic status and academic outcomes in developing countries: A meta-analysis. Review of Educational Research, 89, 875-916. https://doi.org/10.3102/0034654319877155

Kymlicka, W. (2009). Multicultural Odysseys: Navigating the New International Politics of Diversity. Oxford University Press.

Lamb, S. (2011). School dropout and completion in australia. In S. Lamb, E. Markussen, R. Teese, J. Polesel, \& N. Sandberg (Eds.), School dropout and completion (pp. 321-339). Springer Netherlands. https://doi.org/10.1007/978-90-481-9763-7_18

Lamb, S., \& Huo, S. (2017). Counting the costs of lost opportunity in Australian education (02/2017). Mitchell Institute.

http://vuir.vu.edu.au/33523/1/Counting-the-costs-of-lost-opportunity-in-Australian-educatio n.pdf

Lamb, S., Jackson, J., Walstab, A., \& Huo, S. (2015). Educational opportunity in Australia 2015: who succeeds and who misses out. Mitchell Institute. http://www.mitchellinstitute.org.au/wp-content/uploads/2015/11/Educational-opportunity-in -Australia-2015-Who-succeeds-and-who-misses-out-19Nov15.pdf

Lamb, S., \& Markussen, E. (2011). School dropout and completion: an international perspective. In S. Lamb, E. Markussen, R. Teese, J. Polesel, \& N. Sandberg (Eds.), School dropout and completion (pp. 1-18). Springer Netherlands. https://doi.org/10.1007/978-90-481-9763-7_1 
Lansford, J. E., Dodge, K. A., Pettit, G. S., \& Bates, J. E. (2016). A public health perspective on school dropout and adult outcomes: A prospective study of risk and protective factors from age 5 to 27 years. The Journal of Adolescent Health, 58, 652-658.

https://doi.org/10.1016/j.jadohealth.2016.01.014

Lees, A. (2016). Roles of Urban Indigenous Community Members in Collaborative Field-Based Teacher Preparation. Journal of Teacher Education, 67, 363-378. https://doi.org/10.1177/0022487116668018

Lumley, T. (2011). Complex surveys: a guide to analysis using $R$ (Vol. 565). John Wiley \& Sons.

Manojan, K. P. (2018). Indigenous knowledge in education: A study among Paniya tribes in Kerala. Journal of Social Work Education and Practice, 3, 43-55.

Markussen, E., \& Sandberg, N. (2011). Policies to reduce school dropout and increase completion. In S. Lamb, E. Markussen, R. Teese, J. Polesel, \& N. Sandberg (Eds.), School dropout and completion (pp. 391-406). Springer Netherlands. https://doi.org/10.1007/978-90-481-9763-7_22

McRae-Williams, E. (2014). Aspirations for meaningful livelihoods: Challenges of pathway navigation. Journal of Australian Indigenous Issues, 17, 57-71.

Molla, M. T., Madans, J. H., \& Wagener, D. K. (2004). Differentials in adult mortality and activity limitation by years of education in the United States at the end of the 1990s. Population and Development Review, 30, 625-646.

https://doi.org/10.1111/j.1728-4457.2004.00035.x

Morgan, S. L., \& Winship, C. (2015). Counterfactuals And Causal Inference: Methods And 
INDIGENOUS SCHOOL COMPLETION 31

Principles For Social Research (2nd ed.). Cambridge University Press.

Muennig, P. A. (2007). How Education Produces Health: A Hypothetical Framework. Columbia University. https://doi.org/10.7916/d8b858j8

NCVER. (2018). Longitudinal Surveys of Australian Youth (LSAY) 2009 cohort user guide. NCVER. https://www.lsay.edu.au/publications/search-for-lsay-publications/2547

OECD. (2019). Education at a glance 2019. OECD Publishing. https://doi.org/10.1787/eag-2015-en

Oliver, R., \& Exell, M. (2019). Promoting positive self-identity in aboriginal students: Case studies of clontarf academy youth living a rural community. Australian and International Journal of Rural Education, 29, 30-44.

Osborne, N., Howlett, C., \& Grant-Smith, D. (2019). Intersectionality and Indigenous Peoples in Australia: Experiences with Engagement in Native Title and Mining. In O. Hankivsky \& J. S. Jordan-Zachery (Eds.), The palgrave handbook of intersectionality in public policy (pp. 389-411). Springer International Publishing. https://doi.org/10.1007/978-3-319-98473-5_17

Pham, L. (2019). Capital and capabilities in education: Re-examining Australia's 2015 PISA performance and context assessment framework. Policy Futures in Education, 17, 599-617. https://doi.org/10.1177/1478210318808615

Piketty, T. (2014). Capital in the Twenty-First Century. Harvard University Press. https://doi.org/10.4159/9780674369542

Polidano, C., Hanel, B., \& Buddelmeyer, H. (2013). Explaining the socio-economic status school completion gap. Education Economics, 21, 230-247. https://doi.org/10.1080/09645292.2013.789482 
INDIGENOUS SCHOOL COMPLETION 32

Prout, S., \& Hill, A. (2012). Situating Indigenous student mobility within the global education research agenda. International Journal of Educational Research, 54, 60-68. https://doi.org/10.1016/j.ijer.2011.10.005

Reardon, S. F. (2011). The widening academic achievement gap between the rich and the poor: New evidence and possible explanations. In R. Murnane \& G. Duncan (Eds.), Whither opportunity: Rising inequality and the uncertain life chances of low-income children (pp. 91-116). Russell Sage Foundation.

Rumberger, R. W. (2011a). Dropping out : Why students drop out of high school and what can be done about it. Harvard University Press.

Rumberger, R. W. (2011b). High school dropouts in the United States. In S. Lamb, E. Markussen, R. Teese, J. Polesel, \& N. Sandberg (Eds.), School dropout and completion (pp. 275-294). Springer Netherlands. https://doi.org/10.1007/978-90-481-9763-7_16

Sarra, C. (2014). Review of Commonwealth Remote School Attendance Strategy. Department of Prime Minister and Cabinet.

Sikora, J., \& Biddle, N. (2015). How gendered is ambition? Educational and occupational plans of Indigenous youth in Australia. International Journal of Educational Development, 42, 1-13. https://doi.org/10.1016/j.ijedudev.2015.02.011

Silburn, S., Guthridge, S., McKenzie, J., Su, J. Y., \& Haste, S. (2018). Early pathways to school learning: Lessons from the NT data linkage study. Menzies School of Health Research. https://www.menzies.edu.au/icms_docs/293933_Early_Pathways_to_School_Learning_\%E 2\%80\%93_Lessons_from_the_NT_data_linkage_study.pdf

Singar, S. N., \& Zainuddin, A. (2017). Exploring the school dropout factors among Indigenous 
students in Melaka. Journal of Administrative Science, 14. https://jas.uitm.edu.my/images/SPECIALEDITIONVOL3_2017/3.pdf

Song, S., Perry, L. B., \& McConney, A. (2014). Explaining the achievement gap between Indigenous and non-Indigenous students: an analysis of PISA 2009 results for Australia and New Zealand. Educational Research and Evaluation, 20, 178-198. https://doi.org/10.1080/13803611.2014.892432

Sznitman, S. R., Reisel, L., \& Khurana, A. (2017). Socioeconomic background and high school completion: Mediation by health and moderation by national context. Journal of Adolescence, 56, 118-126. https://doi.org/10.1016/j.adolescence.2017.02.004

Thomson, S., De Bortoli, L., \& Buckley, S. (2013). PISA 2012: How Australia measures up. ACER. https://research.acer.edu.au/cgi/viewcontent.cgi?article=1015\&context=ozpisa Tieken, M. C. (2014). Why rural schools matter (1st ed.). The University of North Carolina Press.

United Nations Department of Economic and Social Affairs [UNDESA]. (2020). State of the World's Indigenous Peoples Volume 3 Education. United Nations Department of Economic and Social Affairs. https://www.un.org/development/desa/indigenouspeoples/news/2017/12/state-of-the-worlds -indigenous-peoples-iii-education/

Waldfogel, J., Garfinkel, I., \& Kelly, B. (2005). Public assistance programs: How much could be saved with improved education. Center for Educational Equity. http://www.centerforeducationalequity.org/events-page/equity-symposia/2005-the-social-co sts-of-inadequate-education/papers/waldfogel_paper.ed.pdf 
Walter, M. (2015). The vexed link between social capital and social mobility for Aboriginal and Torres Strait Islander people. Australian Journal of Social Issues, 50, 69-88. https://doi.org/10.1002/j.1839-4655.2015.tb00335.x

Waring, C. D. L. (2017). “It's like we have an ‘in’ already.” Du Bois Review: Social Science Research on Race, 14, 145-163. https://doi.org/10.1017/S1742058X16000357

Wils, A., Sheehan, P., \& Shi, H. (2019). Better secondary schooling outcomes for adolescents in low-and middle-income countries: Projections of cost-effective approaches. Journal of Adolescent Health, 65(1), S25-S33. https://doi.org/10.1016/j.jadohealth.2019.03.024

\section{Tables and Figures}

\section{Table 1}

Descriptive Statistics of Variables

\begin{tabular}{lrr}
\hline Variable & non-Indigenous & Indigenous \\
\hline HS Non-completion \% & $15.83 \%$ & $27.55 \%$ \\
Cohort 2003 & $97.96 \%$ & $2.04 \%$ \\
Cohort 2009 & $96.92 \%$ & $3.08 \%$ \\
Girls \% & $50.14 \%$ & $51.20 \%$ \\
Urban \% & $54.16 \%$ & $45.84 \%$ \\
Year 10 or Higher \% & $90.64 \%$ & $89.98 \%$ \\
Achievement Index (Mean) & $-0.09[-0.13,-0.06]$ & $-0.90[-0.98,-0.82]$ \\
Socioeconomic Status Index (Mean) & $0.31[0.28,0.33]$ & $-0.15[-0.20,-0.10]$ \\
\hline
\end{tabular}

Note. HS $=$ High school. Numbers in square brackets are 95\% Confidence Intervals. 
INDIGENOUS SCHOOL COMPLETION 35

Table 2

Moderators of the Gap between Indigenous and non-Indigenous non-Completion

\begin{tabular}{|c|c|c|c|c|c|c|}
\hline & \multicolumn{3}{|c|}{ Interaction: single-interaction } & \multicolumn{3}{|c|}{ Interaction: multiple-interaction } \\
\hline & Log Odds & $-95 \% \mathrm{CI}$ & $+95 \% \mathrm{CI}$ & Log Odds & $-95 \% \mathrm{CI}$ & $+95 \% \mathrm{CI}$ \\
\hline Indigenous $\mathrm{x}$ & & & & & & \\
\hline SES & 0.584 & 0.371 & 0.796 & 0.574 & 0.369 & 0.779 \\
\hline Indigenous $\mathrm{x}$ & & & & & & \\
\hline Gender (Boys) & -0.313 & -0.745 & 0.119 & -0.321 & -0.711 & 0.069 \\
\hline Indigenous $\mathrm{x}$ & & & & & & \\
\hline Urban & 0.413 & 0.023 & 0.803 & 0.358 & -0.023 & 0.739 \\
\hline Indigenous $\mathrm{x}$ & & & & & & \\
\hline Cohort (2009) & -0.317 & -0.707 & 0.072 & -0.407 & -0.784 & -0.029 \\
\hline
\end{tabular}

Note. Shaded areas are considered significant because the confidence interval does not overlap with zero. SES = socioeconomic status (z-scored).

Table 3

Comparison of Equally Achieving Indigenous and non-Indigenous Youth: Does the Gap Persist?

\begin{tabular}{|c|c|c|c|c|c|c|}
\hline & \multicolumn{3}{|c|}{ Interaction: single-interaction } & \multicolumn{3}{|c|}{ Interaction: multiple-interaction } \\
\hline & Log Odds & $-95 \% \mathrm{CI}$ & $+95 \% \mathrm{CI}$ & Log Odds & $-95 \% \mathrm{CI}$ & $+95 \% \mathrm{CI}$ \\
\hline Indigenous $\mathrm{x}$ & & & & & & \\
\hline SES & 0.478 & 0.248 & 0.707 & 0.385 & 0.162 & 0.607 \\
\hline Indigenous $\mathrm{x}$ & & & & & & \\
\hline Gender (Boys) & -0.381 & -0.846 & 0.084 & -0.326 & -0.73 & 0.077 \\
\hline Indigenous $\mathrm{x}$ & & & & & & \\
\hline Urban & 0.490 & 0.056 & 0.923 & 0.431 & 0.032 & 0.830 \\
\hline Indigenous $\mathrm{x}$ & & & & & & \\
\hline Cohort (2009) & -0.258 & -0.678 & 0.163 & -0.329 & -0.714 & 0.057 \\
\hline Indigenous $\mathrm{x}$ & & & & & & \\
\hline Achievement & 0.388 & 0.18 & 0.596 & 0.306 & 0.087 & 0.526 \\
\hline
\end{tabular}

$\overline{\text { Note. Shaded areas are considered significant because the confidence interval does not overlap }}$ with zero. 


\title{
Table 4
}

Primary Educational Disadvantages for Indigenous Youth

\begin{abstract}
Area Summary
Lack of Too few teachers speak Indigenous languages, basic educational materials

respect and are often sparse, fair information on Indigenous people in educational resources texts are rare, and respect for the diversity Indigenous cultures is lacking.
\end{abstract}

Obstacles to General inequalities in health, welfare and safety, widespread bullying, education cultural discrimination, and equal access to high quality education.

Loss of Lack of integration of Indigenous identity and culture in mainstream identity education.

Invisibility Often Indigenous children's births go unregistered cutting them off from basic rights and protections

Irrelevant Mainstream education is based on the dominant group's culture and education values.

Lack of Governments have increased their focus on and devoted increasing funds foreseeable to tackle gaps but these efforts have often failed to make real sustained solutions progress.

Note. This table summarises findings from the United Nations Department of Economic and Social Affairs (2020). 
INDIGENOUS SCHOOL COMPLETION 37

\section{Figure 1}

Moderation of the Gap in non-Completion Between Indigenous and non-Indigenous Youth
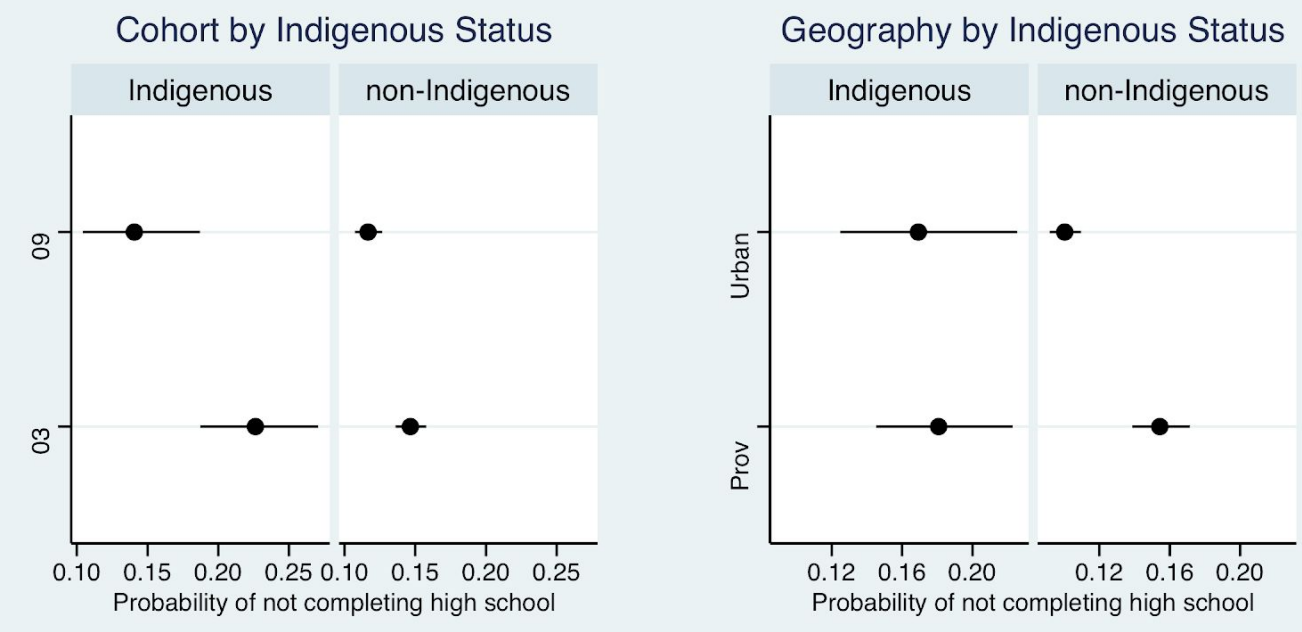

Indig. and non-Indig. Youth

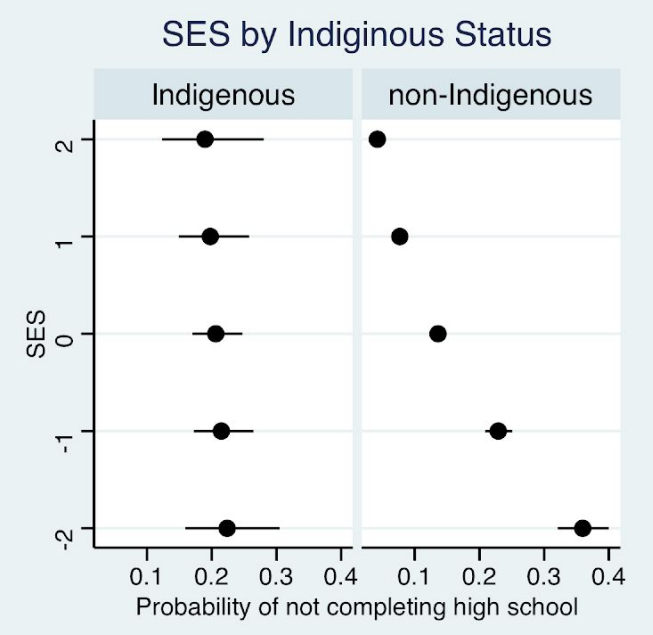

Note. Prov=Provincial or Rural; 03 and 09 indicate LSAY 2003 and 2009 cohort; Indig = Indigenous Status. Socioeconomic status is z-scored. 


\section{Figure 2}

Descriptives for Level of Drop-out and Achievement
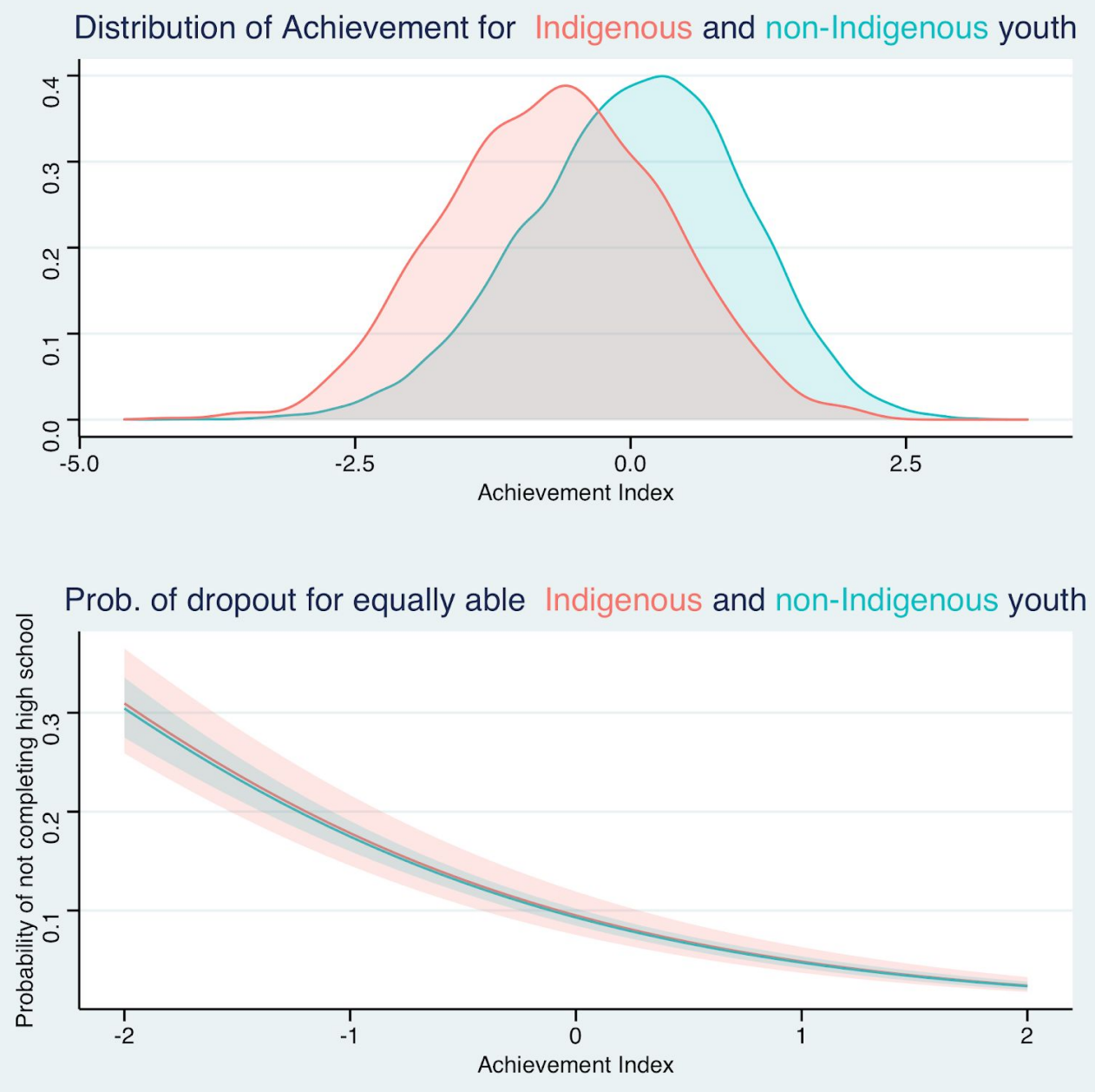

Note . Non-completion $=$ High school non-completion. Indigenous and non-Indigenous youth refer to students of equal ability. 
INDIGENOUS SCHOOL COMPLETION 39

\section{Figure 3}

Moderation of the Gap in Drop-out Between Indigenous and non-Indigenous Youth after Controlling for Academic Achievement

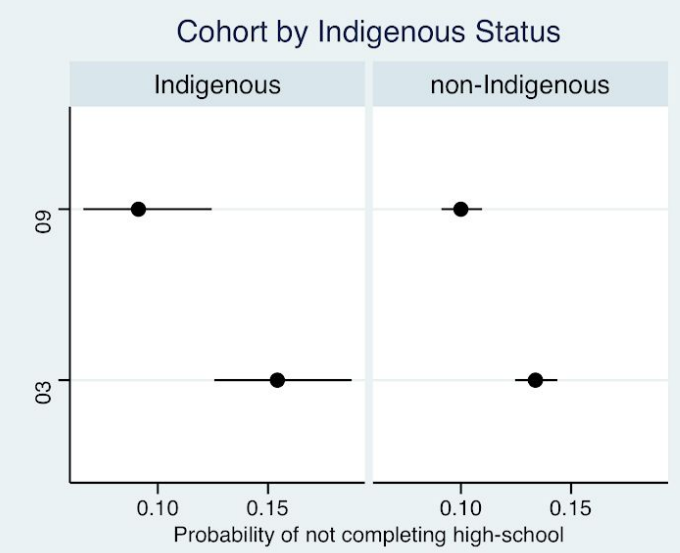

SES by Indiginous Status

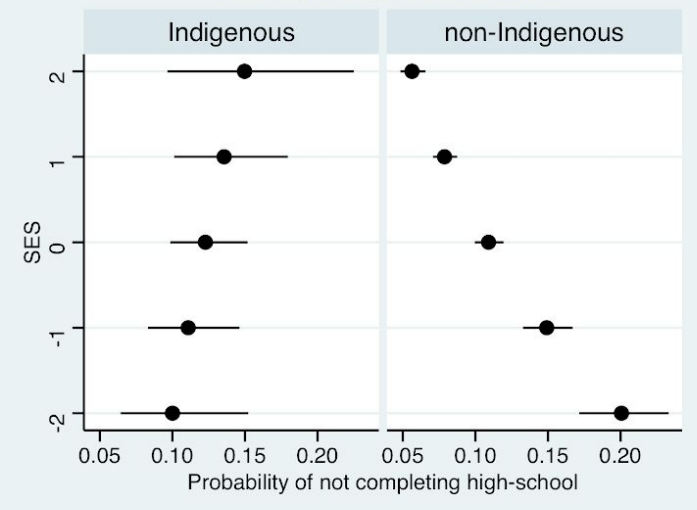

Geography by Indigenous Status

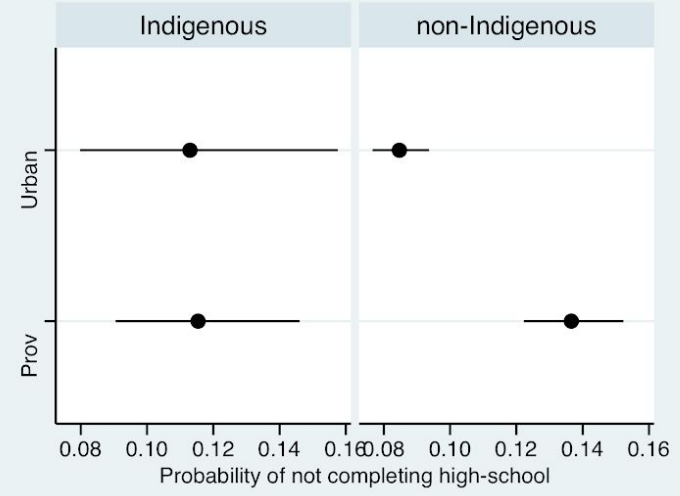

Achievement by Indiginous Status

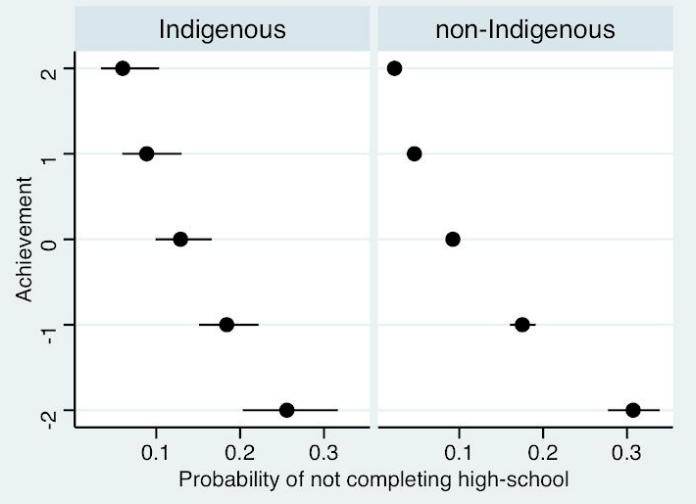

Note. Prov=Provincial or Rural. 


\section{Supplementary materials}

Table S1.

Gender x Indigenous Interaction

\begin{tabular}{lrrrr}
\hline Variables & Log Odds & $-95 \%$ CI & $+95 \%$ CI & $p$ \\
\hline Intercept & 4.768 & 3.897 & 5.639 & $<.001$ \\
Indigenous & 0.528 & 0.16 & 0.896 & 0.006 \\
Gender (Boys) & 0.521 & 0.417 & 0.625 & $<.001$ \\
Cohort (2009) & -0.275 & -0.411 & -0.139 & $<.001$ \\
Grade & -0.642 & -0.725 & -0.558 & $<.001$ \\
Urban & -0.478 & -0.600 & -0.355 & $<.001$ \\
Attrition Flag & 0.613 & 0.501 & 0.726 & $<.001$ \\
SES & -0.618 & -0.685 & -0.551 & $<.001$ \\
Indigenous x & & & & \\
Gender (Boys) & -0.313 & -0.745 & 0.119 & 0.16 \\
\hline
\end{tabular}

Note. $\mathrm{SES}=$ Socioeconomic status (z-scored)

Table S2.

Indigenous $x$ Location Interaction

\begin{tabular}{lrrrr}
\hline Variables & Log Odds & $-95 \%$ CI & $+95 \%$ CI & $p$ \\
\hline Intercept & 4.783 & 3.912 & 5.654 & $<.001$ \\
Indigenous & 0.19 & -0.069 & 0.449 & 0.155 \\
Urban & -0.493 & -0.617 & -0.37 & $<.001$ \\
Cohort (2009) & -0.275 & -0.41 & -0.139 & $<.001$ \\
Grade & -0.641 & -0.725 & -0.558 & $<.001$ \\
Gender & & & & \\
(Boys) & 0.509 & 0.407 & 0.61 & $<.001$ \\
Attrition Flag & 0.613 & 0.501 & 0.726 & $<.001$ \\
SES & -0.618 & -0.685 & -0.551 & $<.001$ \\
Indigenous x & & & & \\
Urban & 0.413 & 0.023 & 0.803 & 0.042 \\
\hline Note. SES Socioecon & & & &
\end{tabular}

Note. SES = Socioeconomic status (z-scored) 
Table S3.

Indigenous $x$ Cohort

\begin{tabular}{lrrrr}
\hline Variables & Log Odds & $-95 \%$ CI & $+95 \%$ CI & $p$ \\
\hline Intercept & 4.762 & 3.892 & 5.631 & $<.001$ \\
SES & -0.618 & -0.685 & -0.551 & $<.001$ \\
Urban & -0.479 & -0.601 & -0.356 & $<.001$ \\
Gender (Boys) & 0.51 & 0.408 & 0.611 & $<.001$ \\
Cohort (2009) & -0.263 & -0.404 & -0.123 & $<.001$ \\
Indigenous & 0.532 & 0.274 & 0.791 & $<.001$ \\
Grade & -0.641 & -0.724 & -0.557 & $<.001$ \\
Attrition Flag & 0.612 & 0.499 & 0.724 & $<.001$ \\
Indigenous x Cohort & & & & 0.115 \\
(2009) & -0.317 & -0.707 & 0.072 & \\
\hline Note. SES Socioeconom
\end{tabular}

Note. SES = Socioeconomic status (z-scored)

Table S4.

All Interactions Entered Simultaneously

\begin{tabular}{lrrrr}
\hline Variables & Log Odds & $-95 \%$ CI & $+95 \%$ CI & $p$ \\
\hline Intercept & 4.752 & 3.878 & 5.626 & $<.001$ \\
Indigenous & 0.729 & 0.347 & 1.11 & $<.001$ \\
SES & -0.637 & -0.705 & -0.568 & $<.001$ \\
Urban & -0.494 & -0.618 & -0.369 & $<.001$ \\
Gender (Boys) & 0.524 & 0.42 & 0.627 & $<.001$ \\
Cohort (2009) & -0.259 & -0.4 & -0.117 & $0.00<.001$ \\
Grade & -0.64 & -0.724 & -0.556 & $<.001$ \\
Attrition Flag & 0.615 & 0.502 & 0.727 & $<.001$ \\
Indigenous x SES & 0.574 & 0.369 & 0.779 & $<.001$ \\
Indigenous x Urban & 0.358 & -0.023 & 0.739 & 0.070 \\
Indigenous x Gender & & & & 0.112 \\
(Boys) & -0.321 & -0.711 & 0.069 & \\
Indigenous x Cohort & & & & 0.039 \\
(2009) & -0.407 & -0.784 & -0.029 &
\end{tabular}

Note. SES = Socioeconomic status (z-scored) 
Table S5.

Main Effects Controlling for Equally Achieving Indigenous and non-Indigenous Youth

\begin{tabular}{lrrrr}
\hline \multicolumn{1}{c}{ Variables } & Log Odds & $-95 \%$ CI & $+95 \%$ CI & $p$ \\
\hline (Intercept) & 1.989 & 1.062 & 2.917 & $<.001$ \\
Location & -0.52 & -0.648 & -0.392 & $<.001$ \\
SES & -0.339 & -0.411 & -0.267 & $<.001$ \\
Gender (Boys) & 0.453 & 0.344 & 0.563 & $<.001$ \\
Indiginous & 0.011 & -0.228 & 0.25 & 0.926 \\
Cohort (2009) & -0.339 & -0.484 & -0.193 & $<.001$ \\
Grade & -0.378 & -0.469 & -0.288 & $<.001$ \\
Attrition Flag & 0.368 & 0.242 & 0.494 & $<.001$ \\
Achievement & -0.734 & -0.802 & -0.666 & $<.001$ \\
\hline
\end{tabular}

Note. SES = Socioeconomic status (z-scored). Achievement is z-scored.

Table S6.

SES Moderation for Equally Achieving Indigenous and non-Indigenous Youth

\begin{tabular}{lrrrr}
\hline Variables & Log Odds & $-95 \%$ CI & $+95 \%$ CI & $p$ \\
\hline (Intercept) & 1.984 & 1.055 & 2.914 & $<.001$ \\
Urban & -0.521 & -0.649 & -0.392 & $<.001$ \\
Gender (Boys) & 0.455 & 0.346 & 0.564 & $<.001$ \\
Indiginous & 0.122 & -0.108 & 0.352 & 0.292 \\
SES & -0.355 & -0.429 & -0.281 & $<.001$ \\
Cohort (2009) & -0.339 & -0.485 & -0.193 & $<.001$ \\
Grade & -0.378 & -0.468 & -0.288 & $<.001$ \\
Attrition Flag & 0.37 & 0.244 & 0.496 & $<.001$ \\
Achievement & -0.733 & -0.801 & -0.664 & $<.001$ \\
Indigenous x SES & 0.478 & 0.248 & 0.707 & $<.001$ \\
\hline Note. SES Socioecom
\end{tabular}

Note. SES = Socioeconomic status (z-scored). Achievement is z-scored. 
Table S7.

Location Moderation for Equally Achieving Indigenous and non-Indigenous Youth

\begin{tabular}{lrrrr}
\hline Variables & Log Odds & $-95 \%$ CI & $+95 \%$ CI & $p$ \\
\hline (Intercept) & 2.002 & 1.074 & 2.931 & $<.001$ \\
Urban & -0.538 & -0.667 & -0.41 & $<.001$ \\
Indigenous & -0.196 & -0.469 & 0.077 & 0.155 \\
Gender (Boys) & 0.453 & 0.344 & 0.562 & $<.001$ \\
SES & -0.339 & -0.411 & -0.267 & $<.001$ \\
Cohort (2009) & -0.338 & -0.483 & -0.193 & $<.001$ \\
Grade & -0.379 & -0.469 & -0.289 & $<.001$ \\
Attrition Flag & 0.369 & 0.243 & 0.494 & $<.001$ \\
Achievement & -0.735 & -0.803 & -0.667 & $<.001$ \\
Indigenous x & & & & 0.027 \\
Urban & 0.49 & 0.056 & 0.923 &
\end{tabular}

Note. SES = Socioeconomic status (z-scored). Achievement is z-scored.

Table S8.

Gender Moderation for Equally Achieving Indigenous and non-Indigenous Youth

\begin{tabular}{lrrrr}
\hline Variables & Log Odds & $-95 \%$ CI & $+95 \%$ CI & $p$ \\
\hline (Intercept) & 1.985 & 1.058 & 2.913 & $<.001$ \\
Urban & -0.52 & -0.648 & -0.391 & $<.001$ \\
Gender (Boys) & 0.468 & 0.357 & 0.579 & $<.001$ \\
Indigenous & 0.209 & -0.186 & 0.604 & 0.293 \\
SES & -0.34 & -0.412 & -0.268 & $<.001$ \\
Cohort (2009) & -0.338 & -0.484 & -0.193 & $<.001$ \\
Grade & -0.379 & -0.469 & -0.289 & $<.001$ \\
Attrition Flag & 0.369 & 0.243 & 0.494 & $<.001$ \\
Achievement & -0.735 & -0.803 & -0.667 & $<.001$ \\
Indigenous x & & & & 0.105 \\
Gender (Boys) & -0.381 & -0.846 & 0.084 & \\
\hline
\end{tabular}

Note. $\mathrm{SES}=$ Socioeconomic status (z-scored). Achievement is z-scored. 
Table S9.

Cohort Moderation for Equally Achieving Indigenous and non-Indigenous Youth

\begin{tabular}{lrrrr}
\hline Variables & Log Odds & $-95 \%$ CI & $+95 \%$ CI & $p$ \\
\hline (Intercept) & 1.984 & 1.057 & 2.911 & $<.001$ \\
Urban & -0.521 & -0.649 & -0.392 & $<.001$ \\
Gender (Boys) & 0.454 & 0.345 & 0.563 & $<.001$ \\
Cohort (2009) & -0.329 & -0.479 & -0.179 & $<.001$ \\
Indigenous & 0.148 & -0.12 & 0.415 & 0.273 \\
SES & -0.339 & -0.411 & -0.267 & $<.001$ \\
Grade & -0.378 & -0.468 & -0.288 & $<.001$ \\
Attrition Flag & 0.367 & 0.242 & 0.493 & $<.001$ \\
Achievement & -0.734 & -0.802 & -0.666 & $<.001$ \\
Indigenous x Cohort & & & & 0.224 \\
(2009) & -0.258 & -0.678 & 0.163 &
\end{tabular}

Note. $\mathrm{SES}=$ Socioeconomic status (z-scored). Achievement is z-scored.

Table S10.

Achievement Moderation

\begin{tabular}{lrrrr}
\hline Variables & Log Odds & $-95 \% \mathrm{CI}$ & $+95 \% \mathrm{CI}$ & $p$ \\
\hline (Intercept) & 1.984 & 1.056 & 2.911 & $<.001$ \\
Urban & -0.522 & -0.65 & -0.394 & $<.001$ \\
Gender (Boys) & 0.455 & 0.346 & 0.564 & $<.001$ \\
Cohort (2009) & -0.341 & -0.487 & -0.195 & $<.001$ \\
Indigenous & 0.444 & 0.14 & 0.747 & 0.005 \\
SES & -0.336 & -0.409 & -0.264 & $<.001$ \\
Grade & -0.379 & -0.469 & -0.289 & $<.001$ \\
Attrition Flag & 0.369 & 0.244 & 0.494 & $<.001$ \\
Achievement & -0.748 & -0.818 & -0.678 & $<.001$ \\
Indigenous x & & & & \\
Achievement & 0.388 & 0.18 & 0.596 & $<.001$ \\
\hline
\end{tabular}

Note. SES = Socioeconomic status (z-scored). Achievement is z-scored. 
Table S11.

All Interactions Entered Simultaneously

\begin{tabular}{lrrrr}
\hline Variables & Log Odds & $-95 \%$ CI & $+95 \%$ CI & $p$ \\
\hline (Intercept) & 1.98 & 1.051 & 2.91 & $<.001$ \\
Urban & -0.54 & -0.669 & -0.411 & $<.001$ \\
Indigenous & 0.602 & 0.154 & 1.049 & 0.009 \\
Gender (Boys) & 0.469 & 0.358 & 0.581 & $<.001$ \\
Cohort (2009) & -0.326 & -0.477 & -0.175 & $<.001$ \\
SES & -0.351 & -0.426 & -0.277 & $<.001$ \\
Grade & -0.379 & -0.469 & -0.288 & $<.001$ \\
Attrition Flag & 0.371 & 0.245 & 0.496 & $<.001$ \\
Achievement & -0.745 & -0.815 & -0.674 & $<.001$ \\
Indigenous x Urban & 0.431 & 0.032 & 0.83 & 0.034 \\
Indigenous x Gender & & & & 0.11 \\
(Boys) & -0.326 & -0.73 & 0.077 & \\
Indigenous x Cohort & & & & 0.092 \\
(2009) & -0.329 & -0.714 & 0.057 & $<.001$ \\
Indigenous x SES & 0.385 & 0.162 & 0.607 & \\
Indigenous x & & & 0.526 & \\
Achievement & 0.306 & 0.087 & & \\
\hline Note SES Socioecono7 & & & & \\
\hline
\end{tabular}

Note. SES = Socioeconomic status (z-scored). Achievement is z-scored. 